\title{
Dodatkowe kryteria wytrzymałościowe dotyczące bezpieczeństwa eksploatacyjnego połączenia wtlaczanego zestawu kołowego
}

\author{
$W$ artykule przedstawiono dodatkowe kryteria wytrzymałościowe, decydujq- \\ ce o bezpieczeństwie zestawów kołowych pojazdów trakcyjnych oraz tocz- \\ nych. Kryteria te obowiqzuja dla przeprowadzonego prawidłowego montażu \\ zestawu kołowego. Przedstawiono aktualny stan wiedzy na temat drgań \\ skrętnych oraz giętnych zestawu kołowego. Omówiono również kryteria, \\ decydujace o wytrzymałości statycznej i zmęczeniowej złącza wtłaczanego.
}

\section{WSTĘP}

Bezpieczeństwo eksploatacyjne zestawu kołowego, jako jednego z najbardziej obciążonego podzespołu pojazdu szynowego trakcyjnego lub tocznego jest

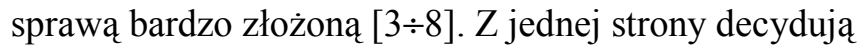
o tym prawidłowo zaprojektowane elementy jak oś lub koło, a z drugiej strony prawidłowo wykonany montaż zestawu kołowego, przeprowadzony $\mathrm{z}$ prawidłowym wciskiem na specjalistycznej prasie.

W przypadku zestawu kołowego kryteria bezpieczeństwa sa przedstawione $\mathrm{w}$ następujących przepisach europejskich:

$>\mathrm{w}$ normie europejskiej PN-EN 13103 +A1:2012 [14] dla metodyki wyznaczania wytrzymałości statycznej i zmęczeniowej osi kolejowych tocznych,

$>\mathrm{w}$ normie europejskiej PN-EN 13104+A2:2013 [15] dla metodyki wyznaczania wytrzymałości statycznej i zmęczeniowej osi kolejowych napędnych,

$>\mathrm{W}$ normie europejskiej PN-EN 139791+A2:2011 [18] dla procedury dopuszczenia kół monoblokowych,

$>\mathrm{w}$ normie europejskiej PN-EN 13715+A1:2011 [17] dla zewnętrznych zarysów wieńców kół,

$>\mathrm{W}$ normie europejskiej PN-EN 13260+A1:2011 [16] dla wymagań, dotyczących gotowych zestawów kołowych,

$>$ w normie europejskiej PN-EN 15313:2010 [19], dotyczącej utrzymania zestawów kołowych pojazdów w eksploatacji i wyłączonych z eksploatacji,

$>$ w karcie UIC 510-2 [11], dotyczącej kół dla pojazdów doczepnych,

$>$ w karcie UIC 510-5 [12], dotyczącej dopuszczenia kół monoblokowych,

$>$ w karcie UIC 813 [13], dotyczącej tolerancji i montażu zestawów kołowych.
Zagadnieniem, które nie jest poruszone w ww. normach jest moment skręcający (niem. „Torsionsmoment”, ang. „torsional torque”), który osiaga największe wartości przy rozruchu lub hamowaniu. W związ$\mathrm{ku} \mathrm{z}$ powyższym istotnym elementem wytrzymałość złącza wtłaczanego piasta koła- podpiaście osi zestawu kołowego. W tym wypadku wytrzymałość złącza wtłaczanego staje się „wąskim gardłem” w procesie projektowania, produkcji oraz utrzymania zestawu kołowego. Najczęściej stosowanym procesem połączenia piasta koła- podpiaście osi (osadzenie) jest połączenie wtłaczane (niem.,,Preßverband”).

\section{POŁĄCZENIE WTŁACZANE, POMIĘDZY PIASTA KOLA ORAZ OSADZENIEM OSI ZESTAWU KOLOWEGO}

Połączenie wtłaczane pomiędzy piastą koła oraz osadzeniem osi jest jednym z dwóch dopuszczonych przez przepisy. Alternatywną możliwością połączenia jest połączenie skurczowe. Najczęściej stosowanym połączeniem jest połączenie wtłaczane. Wymagania dotyczące przebiegu wtłaczania sa przedstawione w załączniku A normy europejskiej PN-EN 13260+A1:2011 [16].

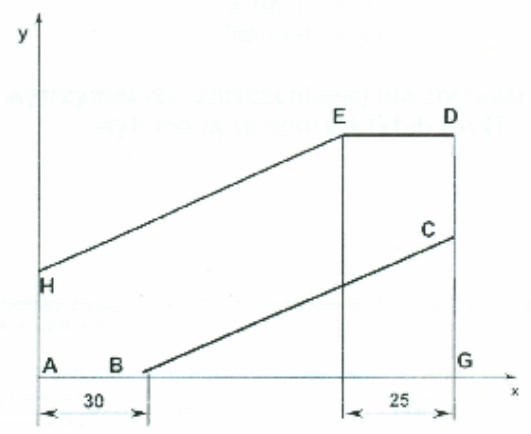

Rys.1. Wykres siły wtłaczania koła na osadzenie osi zgodnie z PNEN 13260:2011 [16] 
Odcinki AB, BC,HE i ED są odcinakami prostych, natomiast odcinek AG odpowiada długości osadzenia. Dla kół lokalizacja różnych punktów jest określona przez następujące wartości:

$\mathrm{Y}_{\mathrm{H}}=1,3 \varnothing$,

$\varnothing$ - nominalna średnica osadzenia koła, w metrach

$\mathrm{Y}_{\mathrm{C}}=0,85 \mathrm{~F}$,

$\mathrm{Y}_{\mathrm{D}}=\mathrm{Y}_{\mathrm{E}}=1,45 \mathrm{~F}$

$\mathrm{F}=$ siła wtłaczania określona przez konstruktora wtłaczanych części (koło, tarcza hamulcowa, koło zębate przekładni itd.)

Objaśnienia dla rys.1:

$\mathrm{x}$-przesunięcie [mm]

y- siła wtłaczania F [MN].

Zgodnie z normą PN-EN 13260+A1:2011 [16] wzrost siły wtłaczania powinien się rozpocząć, zanim przemieszczenie osadzenia na osi $\mathrm{w}$ stosunku do piasty koła wyniesie $30 \mathrm{~mm}$. Potem siła, która była zarejestrowana przed rowkiem, powinna wzrastać w sposób ciagły, jednakże powinna pozostać $\mathrm{w}$ przedziale tolerancji, który został podany przez konstruktora połączenia wtłaczanego.

Norma PN-EN 13260+A1:2011 [16] dopuszcza następujące odstępstwa:

$>$ zmniejszenie siły wtłaczania, gdy przesunięcie osiagnie rowek do wtłaczania oleju; maksymalna siła, która była zarejestrowana przed rowkiem, powinna być ponownie osiagnięta, jeżeli przesunięcie osiągnie następne $25 \mathrm{~mm}$; podczas zmniejszania siły, dopuszczalna jest mniejsza wartość siły wtłaczania, która jest określana za pomocą krzywej;

$>$ dopuszczalny jest spadek siły wtłaczania, wynoszący maksymalnie 5MN, podczas ostatniej fazy przesunięcia, wynoszącej $25 \mathrm{~mm}$

$>$ krzywe mogą wykazywać lokalne odchylenia po uprzednim uzgodnieniu pomiędzy klientem i producentem albo po kwalifikacji wyrobu.

Wymagania techniczne, dotyczace prasy do wtłaczania sa przedstawione w p.3.1.3.2 normy europejskiej PN-EN 13260+A1:2011 [16].

Prasa zastosowana do wtłaczania powinna mieć wzorcowane urządzenie, które rejestruje przebieg siły wtłaczania w funkcji położenia części wtłaczanej na osi. Skala odciętych powinna odpowiadać co najmniej 0,5 krotności rzeczywistego przemieszczenia wtłaczanej części. Skala rzędnych powinna być tak podzielona, żeby można odczytać wartość siły z dokładnością do $0,025 \mathrm{MN}$. Odcięte i rzędne mogą być zamienione. W przypadku rejestracji krzywej w formie zapisu, wykres powinien umożliwić odczyt przemieszczenia $\mathrm{z}$ dokładnością do $1 \mathrm{~mm}$ i zmianą siły $0,025 \mathrm{MN}$.

Wcisk między otworem piasty koła i osadzeniem osi powinien wynosić:

$>$ dla połączeń skurczowych: 0,0009 $\mathrm{dm} \leq \mathrm{j} \leq 0,0015 \mathrm{dm}$
$>$ dla połączeń wtłaczanych: 0,0010 $\mathrm{dm} \leq \mathrm{j} \leq 0,0015 \mathrm{dm}+0,06$

gdzie dm jest średnią średnicą połączenia wtłaczanego w mm.

W celu umożliwienia przeniesienia sił i momentów przez łączone części za pomocą wtłaczania lub połączenia skurczowego, bez wzajemnego ich przemieszczenia, części te powinny wytrzymać przez 30 sekund siłę $\mathrm{F}$, która działa w kierunku wzdłużnym na oś zestawu kołowego.

Jeżeli konstruktor nie ustali specjalnych wymagań dla kół, to wówczas wartość siły F w MN wynosi:

$$
\mathrm{F}=4 \cdot 10^{-3} \cdot \mathrm{dm}
$$

Wartość ta obowiązuje dla zależności:

gdzie:

$$
0,8 \mathrm{dm}<\mathrm{L}<1,1 \mathrm{dm}
$$

dm- średnia średnica osadzenia,

L- długość połączenia wtłaczanego w mm.

Aby sprawdzić jakość połączenia wtłaczanego, wykonuje się próbę sprawdzającą na prasie, wyposażoną $\mathrm{w}$ przyrząd do rejestracji siły. Siłę pomiędzy wewnętrzną powierzchnią piasty montowanych części i osadzeniem osi wprowadza się stopniowo, aż zostanie osiągnięta wartość siły F. Próbę należy przeprowadzić po upływie 48 godzin po przeprowadzeniu montażu.

Dla kół łączonych skurczowo test należy przeprowadzić, kiedy koła i oś powrócą do tej samej temperatury przed montażem.

W tabeli 1 przedstawiono wartości siły wtłaczania wg zależności (1), własności geometryczne osadzenia oraz wymagane wartości wcisku dla wybranych średnic osadzenia osi zestawów kołowych.

Jak wynika z zależności (1) wartość wymaganej siły wtłaczania jest stała i zależy tylko i wyłącznie od średnicy osadzenia połączenia wtłaczanego.

Należy jednak pamiętać, że podczas wtłaczania używany jest środek smarny, który wpływa na wielkość siły wtłaczania. Zagadnienie to jest opisane w karcie UIC 813 [13].

Siłę wtłaczania piasty koła zgodnie z kartą UIC 813 [13] p.5.2.3.3.5 wynosi:

$$
\mathrm{P}_{\mathrm{F}}=\mathrm{a} \cdot \mathrm{D}
$$

gdzie:

D-nominalna średnica $\mathrm{w}$ mm

a-współczynnik wg tabeli 2,

$\mathrm{P}_{\mathrm{F}}$ - siła wtłaczania $\mathrm{w} \mathrm{kN}$.

Wartości dopuszczalne sił wtłaczania w zależności od użytego rodzaju środka smarnego, rodzaju wtłaczanych kół oraz rodzaju pojazdu (tabor toczny oraz tabor trakcyjny) są przedstawione w tabeli 2 . 
Zestawienie sil wtlaczania, wlasności geometrycznych oraz wymaganych wartości wcisku dla wybranych średnic osadzenia osi dla wtlaczanych kól zestawów kołowych

Tabela 1

\begin{tabular}{|c|c|c|c|c|c|c|}
\hline L.p. & Typ osi & $\begin{array}{c}\text { Średnica osa- } \\
\mathbf{d z e n i a} \\
\mathbf{d m}[\mathbf{m m}]\end{array}$ & $\begin{array}{c}\text { Długość } \\
\text { osadzenia } \\
\mathbf{L}[\mathbf{m m}]\end{array}$ & $\begin{array}{c}\text { Stosunek } \\
\mathbf{L / d m}\end{array}$ & $\begin{array}{c}\text { Sila } \\
{[\mathbf{k N}]}\end{array}$ & $\begin{array}{c}\text { Wcisk } \\
{[\mathbf{m m}]}\end{array}$ \\
\hline 1 & Ośtypu A & 185 & 185 & 1 & 740 & 0,3375 \\
\hline 2 & Ośtypu B & 200 & 200 & 1 & 800 & 0,36 \\
\hline 3 & Oś 38 MN & 185 & 196 & 0,94 & 740 & 0,3375 \\
\hline 4 & Oś 34MN & 185 & 165 & 0,89 & 740 & 0,3375 \\
\hline 5 & Oś 111E & 233 & 191 & 0,81 & 932 & 0,4095 \\
\hline
\end{tabular}

Zestawienie współczynnika „a” sil wtlaczania w zależności od użytego rodzaju środka smarnego, rodzaju kół (koła bose, koła obręczowane, koła monoblokowe), rodzaju taboru (tabor toczny i trakcyjny) wg karty UIC 813 [13]

Tabela 2

\begin{tabular}{|c|c|c|c|c|}
\hline & 1 & 2 & 3 & 4 \\
\hline & \multicolumn{4}{|c|}{ smar użyty podczas wtlaczania } \\
\hline & $\overline{\text { olej } j^{2)}}$ & lój & olej+lój $^{1)}$ & $\mathrm{MoS2}^{3)}$ \\
\hline $\begin{array}{l}\text { Koło bose } \\
\text { Wagony }\end{array}$ & $3,5 \div 5$ & $3,0 \div 4,5$ & $3,25 \div 3,5$ & $3,0 \div 4,5$ \\
\hline $\begin{array}{c}\text { Koła monoblokowe } \\
\text { Koło obręczowane } \\
\text { Wagony }\end{array}$ & $4,0 \div 6,0$ & $3,0 \div 5,5$ & $3,5 \div 5,75$ & $3,0 \div 5,5$ \\
\hline $\begin{array}{l}\text { Koła monoblokowe } \\
\text { Koła obręczowane } \\
\text { Tabor trakcyjny }\end{array}$ & $4,5 \div 6,5$ & $3,0 \div 6,0$ & $3,75 \div 6,25$ & $3,5 \div 6,0$ \\
\hline
\end{tabular}

1) W przypadku stosowania mieszanki smarnej olej+ tój należy stosować średnie wartości z kolumn 1+2.

2) Przez olej jako środek umożliwiajacy wtłaczanie, rozumie się olej roślinny, czyli olej lniany, rzepikowy, rzepakowy.

3) Dwusiarczek molibdenu

Zestawienie sił wtlaczania, własności geometrycznych dla wybranych średnic osadzenia osi dla wtlaczanych kól zestawów kołowych wg karty UIC 813 [13]

\begin{tabular}{|c|c|c|c|c|c|c|}
\hline L.p. & Typ osi & $\begin{array}{c}\text { Typ } \\
\text { środka } \\
\text { smarnego }\end{array}$ & $\begin{array}{c}\mathrm{D} \\
{[\mathrm{mm}]}\end{array}$ & $\begin{array}{c}\mathrm{L} \\
{[\mathrm{mm}]}\end{array}$ & $\begin{array}{l}\text { Siła } \\
\mathrm{F}_{\mathrm{MIN}} \\
{[\mathrm{kN}]}\end{array}$ & $\begin{array}{l}\text { Siła } \\
\text { F }_{\mathrm{MAX}} \\
{[\mathrm{kN}]}\end{array}$ \\
\hline \multirow{4}{*}{1.} & \multirow{4}{*}{$\begin{array}{c}\text { Oś typu A } \\
\text { wagon towarowy } \\
\text { z kołami monobloko- } \\
\text { wymi }\end{array}$} & olej & \multirow{4}{*}{185} & \multirow{4}{*}{185} & 740 & 1110 \\
\hline & & tój & & & 555 & 1018 \\
\hline & & olej +łój & & & 647,5 & 1063,75 \\
\hline & & $\mathrm{MoS}_{2}$ & & & 555 & 1018 \\
\hline \multirow{4}{*}{2.} & \multirow{4}{*}{$\begin{array}{c}\text { Oś typu B } \\
\text { wagon towarowy z } \\
\text { kołami monobloko- } \\
\text { wymi }\end{array}$} & olej & \multirow{4}{*}{200} & \multirow{4}{*}{200} & 800 & 1200 \\
\hline & & tój & & & 600 & 1100 \\
\hline & & olej +łój & & & 700 & 1150 \\
\hline & & $\mathrm{MoS}_{2}$ & & & 600 & 1100 \\
\hline \multirow{4}{*}{3.} & \multirow{4}{*}{$\begin{array}{l}\text { Oś 38MN zespołu } \\
\text { trakcyjnego }\end{array}$} & olej & \multirow{4}{*}{185} & \multirow{4}{*}{196} & 832,5 & 1202,5 \\
\hline & & łój & & & 555 & 1110 \\
\hline & & Olej +łój & & & 693,75 & 1156,25 \\
\hline & & $\mathrm{MoS}_{2}$ & & & 647,5 & 1110 \\
\hline \multirow{4}{*}{4.} & \multirow{4}{*}{$\begin{array}{l}\text { Oś } 34 \mathrm{MN} \text { pojazdu } \\
\text { trakcyjnego }\end{array}$} & Olej & \multirow{4}{*}{185} & \multirow{4}{*}{165} & 832,5 & 1202,5 \\
\hline & & tój & & & 555 & 1110 \\
\hline & & olej +łój & & & 693,75 & 1156,25 \\
\hline & & $\mathrm{MoS}_{2}$ & & & 647,5 & 1110 \\
\hline \multirow{4}{*}{5.} & \multirow{4}{*}{$\begin{array}{c}\text { Oś lokomotywy } \\
\text { elektrycznej typu } \\
111 \mathrm{E}\end{array}$} & olej & \multirow{4}{*}{233} & \multirow{4}{*}{191} & 1048,5 & 1514,5 \\
\hline & & lój & & & 699 & 1398 \\
\hline & & olej +łój & & & 873,75 & 1456,25 \\
\hline & & $\mathrm{MoS}_{2}$ & & & 815,5 & 1398 \\
\hline
\end{tabular}

Tabela 3 
Maksymalna siła wtłaczania może przekraczać wartości wyznaczone w tabeli 3 , ale nie więcej niż $10 \%$.

Siły wtłaczania, przedstawione $\mathrm{w}$ tabeli 3 można uznać jako kryteria. Aby spełnić ww. kryteria wartości sił wtłaczania należy dobrać odpowiedni wcisk dla połączenia wtłaczanego oraz odpowiedni środek smarny.

Biorąc pod uwagę dwa parametry tzn. współczynnik tarcia oraz naciski powierzchniowe pomiędzy piastą koła i osadzeniem osi minimalną siłę wtłaczania można wyznaczyć ze wzoru:

gdzie:

$\mathrm{F}_{\mathrm{MIN}^{-}}$minimalna siła wtłaczania $[\mathrm{N}]$,

1- długość połączenia wtłaczanego [mm],

D-średnica osadzenia [mm],

$\mathrm{P}_{\mathrm{MIN}}$ - nacisk jednostkowy pomiędzy osadzeniem osi oraz piastą koła [MPa],

$\mu_{\mathrm{MIN}^{-}}$minimalny współczynnik tarcia podczas wtłaczania pomiędzy piasta koła oraz podpiaściem osi, którego wartość zawiera się pomiędzy $0,08 \div 0,12 ; \mathrm{w}$ przypadku minimalnej wartości wynosi $0,08[-]$.

Natomiast maksymalną siłę wtłaczania można wyznaczyć analogicznie ze wzoru:

$$
\mathrm{F}_{\mathrm{MAX}}=\pi \cdot 1 \cdot \mathrm{D} \cdot \mathrm{p}_{\mathrm{MAX}} \cdot \mu_{\mathrm{MAX}}
$$

gdzie:

$\mathrm{F}_{\mathrm{MAX}}-$ maksymalna siła wtłaczania $[\mathrm{N}]$,

1- długość połączenia wtłaczanego [mm],

D-średnica osadzenia [mm],

$\mathrm{P}_{\mathrm{MAX}}$ - nacisk jednostkowy pomiędzy osadzeniem osi oraz piastą koła [MPa],

$\mu_{\mathrm{MAX}}$ maksymalny współczynnik tarcia podczas wtłaczania wynosi 0,12 .

Wcisk dobiera się zgodnie z załącznikiem A karty UIC 813 [13], który wynika z:

$>$ pasowania pomiędzy piastami i podpiaściami dla średnic w zakresie 100 do $300 \mathrm{~mm}$, jak również z odpowiedniej klasy tolerancji dla klasy odchyłek V zgodnie z normą ISO 286 [20]

$>$ pasowania między piastami i podpiaściami dla średnic w zakresie 100 do $300 \mathrm{~mm}$ i klasy tolerancji odpowiadającej klasie odchyłek U wg ISO 286 [17].

Do pierwszej grupy pasowań należy zaliczyć zgodnie z załącznikiem A.1.1 karty UIC 813 [13] należy zaliczyć następujące pasowania: H6/v6, H6/v7, H7/v6,

Zestawienie odchyłek dla pasowań H6/v6, H6/v7, H7/v6, H8/v6 i H8/v7 oraz wynikających wcisków minimalnych, maksymalnych oraz średnich dla połączeń wtlaczanych koło-osadzenie osi (średnica $185 \mathrm{~mm}$ )

Tabela 4

\begin{tabular}{|c|c|c|c|c|c|c|}
\hline L.p. & $\begin{array}{c}\text { Pasowanie } \\
{[-]}\end{array}$ & $\begin{array}{c}\text { odchyłki otwo- } \\
\text { ru } \\
{[\mathrm{mm}]}\end{array}$ & $\begin{array}{c}\text { odchyłki } \\
\text { osadzenia osi } \\
{[\mathrm{mm}]}\end{array}$ & $\begin{array}{c}\text { wcisk mini- } \\
\text { malny } \\
{[\mathrm{mm}]}\end{array}$ & $\begin{array}{c}\text { wcisk } \\
\text { maksymalny } \\
{[\mathrm{mm}]}\end{array}$ & $\begin{array}{c}\text { wcisk } \\
\text { średni } \\
{[\mathrm{mm}]}\end{array}$ \\
\hline 1. & H6/v6 & $\begin{array}{c}+0,029 \\
0\end{array}$ & $\begin{array}{l}+0,313 \\
+0,284\end{array}$ & 0,255 & 0,313 & 0,2840 \\
\hline 2. & H6/v7 & $\begin{array}{c}+0,029 \\
0 \\
\end{array}$ & $\begin{array}{r}+0,330 \\
+0,284 \\
\end{array}$ & 0,255 & 0,330 & 0,2925 \\
\hline 3. & H7/v6 & $\begin{array}{c}+0,046 \\
0 \\
\end{array}$ & $\begin{array}{r}+0,313 \\
+0,284 \\
\end{array}$ & 0,238 & 0,313 & 0,2755 \\
\hline 4. & H7/v7 & $\begin{array}{c}+0,046 \\
0\end{array}$ & $\begin{array}{l}+0,330 \\
+0,284\end{array}$ & 0,238 & 0,330 & 0,284 \\
\hline 5. & H8/v6 & $\begin{array}{c}+0,072 \\
+0\end{array}$ & $\begin{array}{l}+0,313 \\
+0,284\end{array}$ & 0,212 & 0,313 & 0,2625 \\
\hline 6. & $\mathrm{H} 8 / \mathrm{v} 7$ & $\begin{array}{c}+0,072 \\
0\end{array}$ & $\begin{array}{l}+0,330 \\
+0,284\end{array}$ & 0,212 & 0,330 & 0,271 \\
\hline
\end{tabular}

Zestawienie odchyłek dla pasowań H6/u6, H6/u7,H6/u8, H7/u6, H7/u7, H7/u8 oraz wynikających wcisków minimalnych, maksymalnych oraz średnich dla połączeń wtlaczanych koło-osadzenie osi (średnica 185 mm)

\begin{tabular}{|c|c|c|c|c|c|c|}
\hline L.p. & $\begin{array}{c}\text { pasowanie } \\
{[-]}\end{array}$ & $\begin{array}{c}\text { odchyłki otwo- } \\
\text { ru } \\
{[\mathrm{mm}]}\end{array}$ & $\begin{array}{c}\text { odchyłki } \\
\text { osadzenia osi } \\
{[\mathrm{mm}]}\end{array}$ & $\begin{array}{c}\text { wcisk mini- } \\
\text { malny } \\
{[\mathrm{mm}]}\end{array}$ & $\begin{array}{c}\text { wcisk } \\
\text { maksymalny } \\
{[\mathrm{mm}]}\end{array}$ & $\begin{array}{c}\text { wcisk } \\
\text { średni } \\
{[\mathrm{mm}]}\end{array}$ \\
\hline 1. & H6/u6 & $\begin{array}{c}+0,029 \\
0\end{array}$ & $\begin{array}{l}+0,265 \\
+0,236\end{array}$ & 0,207 & 0,265 & 0,236 \\
\hline 2. & $\mathrm{H} 6 / \mathrm{u} 7$ & $\begin{array}{c}+0,029 \\
0 \\
\end{array}$ & $\begin{array}{l}+0,282 \\
+0,236 \\
\end{array}$ & 0,207 & 0,282 & 0,2445 \\
\hline 3. & H6/u8 & $\begin{array}{c}+0,029 \\
0\end{array}$ & $\begin{array}{l}+0,308 \\
+0,236 \\
\end{array}$ & 0,207 & 0,308 & 0,249 \\
\hline 4. & H7/u6 & $\begin{array}{c}+0,046 \\
0\end{array}$ & $\begin{array}{l}+0,265 \\
+0,236 \\
\end{array}$ & 0,190 & 0,265 & 0,2275 \\
\hline 6. & $\mathrm{H} 7 / \mathrm{u} 7$ & $\begin{array}{c}+0,046 \\
0\end{array}$ & $\begin{array}{l}+0,282 \\
+0,236\end{array}$ & 0,190 & 0,282 & 0,236 \\
\hline 7. & $\mathrm{H} 7 / \mathrm{u} 8$ & $\begin{array}{c}+0,046 \\
0 \\
\end{array}$ & $\begin{array}{l}+0,308 \\
+0,236 \\
\end{array}$ & 0,190 & 0,308 & 0,249 \\
\hline
\end{tabular}


H7/v7, H8/v6,H8/v7 (rys.2). Wciski minimalne i maksymalne wynikające $\mathrm{z}$ ww. pasowań są zamieszczone w tabeli 4.

Do drugiej grupy zgodnie z załącznikiem A.1.2 karty UIC 813 [13] należy zaliczyć następujące pasowania: H6/u6, H6/u7,H6/u8, H7/u6, H7/u6, H7/u7, H7/u8. Wciski minimalne i maksymalne wynikające $\mathrm{z}$ ww. pasowań są zamieszczone w tabeli 5 .

Jak widać $\mathrm{z}$ porównania tabeli 4 i 5 pierwsza grupa pasowań, przewidzianych do otworu koła i osadzenia osi zestawu kołowego daje większe wciski minimalne, maksymalne oraz średnie niż druga grupa pasowań. W przypadku jeśli konstruktor nie ustalił żadnych szczególnych wymagań, to wartość wcisku należy ustalić zgodnie z p.3.1.2 PN-EN 13260+A1:2011 [16] oraz załącznikiem A1.1 i A1.2 karty UIC 813 [13]. Wcisk maksymalny $\mathrm{J}_{\mathrm{MAX}}[\mathrm{mm}]$ wyznacza się ze wzoru:

$$
\mathrm{J}_{\mathrm{MAX}}=0,0015 \mathrm{D}+0,06
$$

Wcisk minimalny $\mathrm{J}_{\mathrm{MIN}}[\mathrm{mm}]$ wyznacza się ze wzoru:

$$
\mathrm{J}_{\mathrm{MIN}}=0,0009 \mathrm{D}
$$

Nacisk jednostkowy p pomiędzy elementami wtłaczanymi (osadzenie osi) oraz elementami obejmujaccymi (piasta koła) można wyznaczyć ze wzoru:

$$
\mathrm{p}=\frac{\mathrm{J}}{\mathrm{D}} \cdot \frac{1}{\frac{\mathrm{c}_{1}-\mathrm{v}_{1}}{\mathrm{E}_{1}}+\frac{\mathrm{c}_{2}+\mathrm{v}_{2}}{\mathrm{E}_{2}}}
$$

gdzie:

p- nacisk powierzchniowy pomiędzy wewnętrzną powierzchnią piasty koła, a podpiaściem (osadzeniem osi),

J- wcisk pomiędzy średnicą osadzenia osi a średnicą piasty koła,

D- średnica osadzenia podpiaścia osi zestawu kołowego,

$\mathrm{c}_{1}, \mathrm{c}_{2}$ - współczynniki określane z zadania Lamego,

$v_{1}$-współczynnik Poissona materiału osi,

$\mathrm{V}_{2}$ - współczynnik Poissona materiału koła,

$\mathrm{E}_{1}$ - moduł Younga materiału osi,

$\mathrm{E}_{2}$-moduł Younga materiału koła.

Współczynniki $\mathrm{c}_{1}$ i $\mathrm{c}_{2}$ można wyznaczyć ze wzorów:

gdzie:

$$
\begin{gathered}
c_{1}=\frac{1+\left(\frac{D_{1}}{D^{2}}\right)^{2}}{1-\left(\frac{D_{1}}{D}\right)^{2}} \\
c_{2}=\frac{1+\left(\frac{D}{D_{2}}\right)^{2}}{1-\left(\frac{D}{D_{2}}\right)^{2}}
\end{gathered}
$$

przypadku pełnych osi $\mathrm{D}_{1}=0$

$\mathrm{D}_{2}$-średnica zewnętrzna piasty koła.
W przypadku osi pełnych współczynnik $\mathrm{c}_{1}=1$, gdyż $\mathrm{D}_{1}=\mathrm{D}$.

Ponieważ koło (piasta koła) oraz oś zestawu kołowego, wykonane są ze stali to wówczas $E_{1}=E_{2}$ oraz $v_{1}=v_{2}$.

Wówczas zależność (8) przyjmuje postać:

$$
\mathrm{p}=\frac{\mathrm{J}}{\mathrm{D}} \cdot \frac{\mathrm{E}}{\mathrm{c}_{1}+\mathrm{c}_{2}}
$$

Zebranie kryteriów wcisków $\mathrm{J}_{\mathrm{MAX}}$ oraz $\mathrm{J}_{\mathrm{MIN}}$ dla wybranych połączeń wtłaczanych koło-oś zestawów kołowych przedstawiono w tabeli 6 .

Zestawienie wcisków $\mathbf{J}_{\text {MAX }}$ oraz $\mathbf{J}_{\text {MIN }}$ dla połączeń wtlaczanych piasta koła-osadzenie osi wybranych zestawów kołowych

Tabela 6

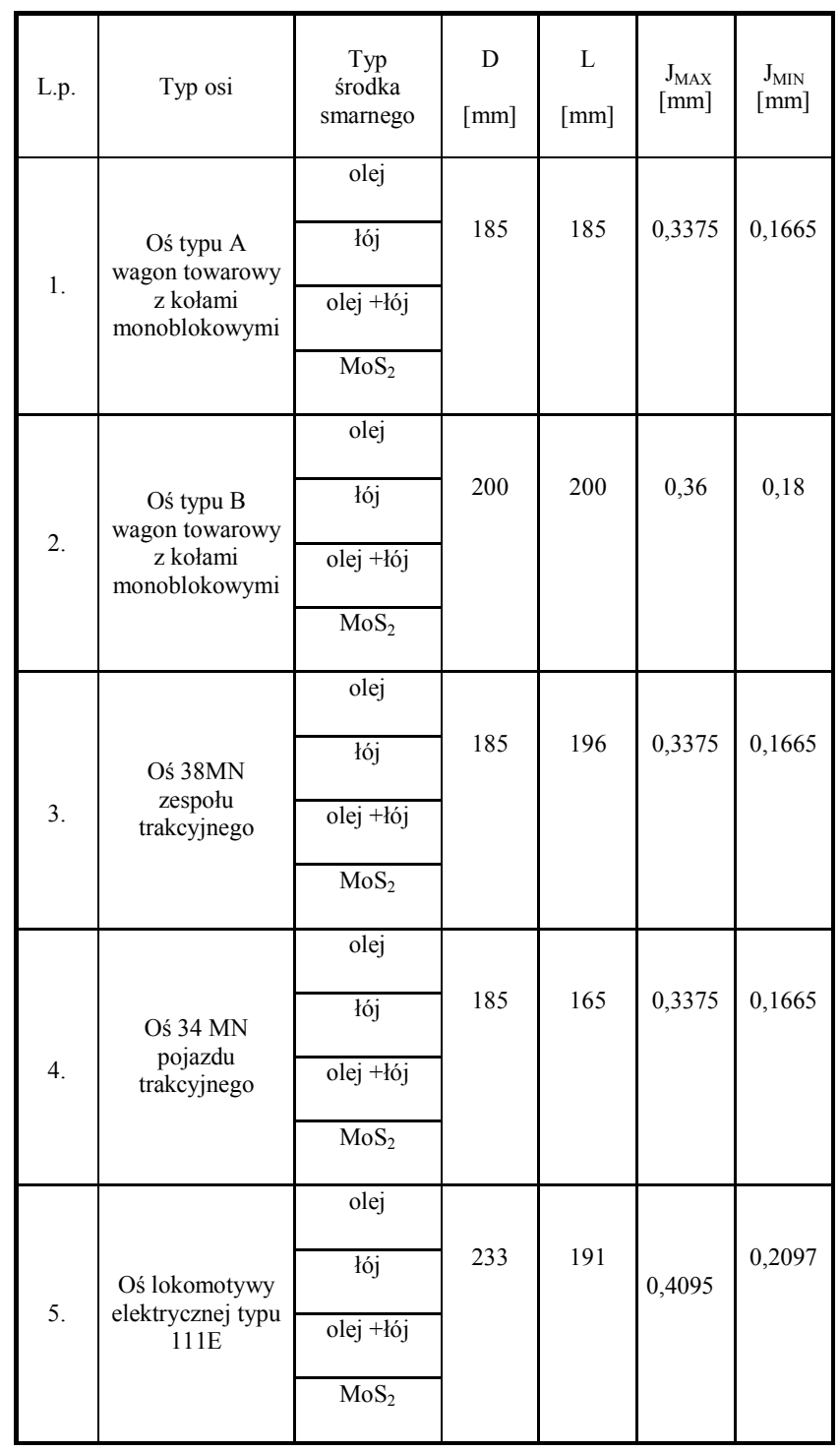

Poniżej podano przykład obliczeniowy dla osi typu A wagonu towarowego oraz koła monoblokowego BA005 o średnicy zewnętrznej $\mathrm{D}_{2}=300 \mathrm{~mm}$.

Po wstawieniu danych liczbowych do wzoru (9):

$$
\mathrm{c}_{1}=1
$$

Po wstawieniu wartości liczbowych $\mathrm{D}=185 \mathrm{~mm}$ oraz $\mathrm{D}_{2}=300 \mathrm{~mm}$ do wzoru (10) otrzymuje się: 


$$
c_{2}=\frac{1+\left(\frac{185}{300}\right)^{2}}{1-\left(\frac{185}{300}\right)^{2}}=2,22725
$$

Po wstawieniu $\mathrm{D}=185 \mathrm{~mm}$ do wzoru (7) otrzymuje się:

$$
\mathrm{J}_{\mathrm{MIN}}=0,0009 \cdot 185=0,1665 \mathrm{~mm}
$$

Po wstawieniu wartości liczbowych do wzoru (11) tzn. $\mathrm{E}=2,06 \cdot 10^{11} \mathrm{~N} / \mathrm{mm}^{2}=2,06 \cdot 10^{5} \mathrm{MPa}, \mathrm{J}_{\mathrm{MIN}}=0,1665 \mathrm{~mm}$, $\mathrm{c}_{1}=1$ oraz $\mathrm{c}_{2}=2,22725$ do wzoru (11) otrzymuje się:

$$
\mathrm{p}_{\text {MIN }}=\frac{0,1665}{185} \cdot \frac{2,06 \cdot 10^{5}}{1+2,22725}=57,44 \mathrm{MPa}
$$

Po wstawieniu $\mathrm{D}=185 \mathrm{~mm}$ do wzoru (6) otrzymuje się:

$$
\mathrm{J}_{\mathrm{MAX}}=0,0015 \cdot 185+0,06=0,3375 \mathrm{~mm}
$$

Po wstawieniu wartości liczbowych do wzoru (11) tzn. . $E=2,06 \cdot 10^{11} \mathrm{~N} / \mathrm{mm}^{2}=2,06 \cdot 10^{5} \mathrm{MPa}, \mathrm{J}_{\mathrm{MIN}}=0,3375 \mathrm{~mm}$, $c_{1}=1$ oraz $c_{2}=2,22725$ do wzoru (11) otrzymuje się:

$$
\mathrm{p}_{\mathrm{MAX}}=\frac{0,3375}{185} \cdot \frac{2,06 \cdot 10^{5}}{1+2,22725}=116,44 \mathrm{MPa}
$$

Podstawiając do wzoru (4) wartości $\mu=0,08,1=0,185$ $\mathrm{m}, \mathrm{D}=0,185 \mathrm{~m}, \mathrm{p}_{\mathrm{MIN}}=57,44 \mathrm{MPa}$ otrzymuje się wartości następujące:

$$
\mathrm{F}_{\mathrm{MIN}}=\pi \cdot 0,185 \cdot 0,185 \cdot 57,44 \cdot 10^{6} \cdot 0,08 \cdot 10^{-3}=494,08 \mathrm{kN}
$$

Podstawiając do wzoru (5) wartości $\mu=0,08,1=0,185$ $\mathrm{m}, \mathrm{D}=0,185 \mathrm{~m}, \mathrm{p}_{\mathrm{MIN}}=116,44 \mathrm{MPa}$ otrzymuje się wartości następujące:

$$
\mathrm{F}_{\mathrm{MAX}}=\pi \cdot 0,185 \cdot 0,185 \cdot 116,44 \cdot 10^{6} \cdot 0,12 \cdot 10^{-3}=1502,36
$$

Biorąc pod uwagę, że wartości sił wtłaczania we wzorze (19) oraz (19) są wyliczone w oparciu o skrajne wartości wcisku tzn. wartości minimalne oraz wartości maksymalne, które są możliwe, ale mało prawdopodobne wydaje się celowe sprawdzenie sił wtłaczania dla wcisków średnich.

Zakładając, że $\mathrm{J}_{\mathrm{MIN}}=0,1665 \mathrm{~mm}$ oraz $\mathrm{J}_{\mathrm{MAX}}=0,3375 \mathrm{~mm}$ wcisk średni $\mathrm{J}_{\mathrm{SR}}=0,252 \mathrm{~mm}$.

Wówczas po wstawieniu wartości liczbowych do wzo$\mathrm{ru}$ (11) tzn. $\mathrm{E}=2,06 \cdot 10^{11} \mathrm{~N} / \mathrm{mm}^{2}=2,06 \cdot 10^{5} \mathrm{MPa}$, $\mathrm{J}_{\mathrm{S} \mathrm{R}}=0,252 \mathrm{~mm}, \mathrm{c}_{1}=1$ oraz $\mathrm{c}_{2}=2,22725$ do wzoru (11) otrzymuje się:

$$
\mathrm{p}_{\mathrm{SR}}=\frac{0,252}{185} \cdot \frac{2,06 \cdot 10^{5}}{1+2,22725}=86,94 \mathrm{MPa}
$$

Podstawiając do wzoru (4) wartości $\mu=0,08,1=0,185$ $\mathrm{m}, \mathrm{D}=0,185 \mathrm{~m}, \mathrm{p}_{\mathrm{MIN}}=86,94 \mathrm{MPa}=86,94 \cdot 10^{6} \mathrm{~N} / \mathrm{m}^{2}$ otrzymuje się wartości następujące:

$$
\mathrm{F}_{\mathrm{MIN}}=\pi \cdot 0,185 \cdot 0,185 \cdot 86,94 \cdot 10^{6} \cdot 0,08 \cdot 10^{-3}=747 \mathrm{kN}
$$

Podstawiając do wzoru (5) wartości $\mu=0,12 \quad l=0,185$ $\mathrm{m}, \mathrm{D}=0,185 \mathrm{~m}, \mathrm{p}_{\mathrm{MIN}}=86,94 \mathrm{MPa}=86,94 \cdot 10^{6} \mathrm{~N} / \mathrm{m}^{2}$ otrzymuje się wartości następujące:

$$
\mathrm{F}_{\mathrm{MAX}}=\pi \cdot 0,185 \cdot 0,185 \cdot 86,94 \cdot 10^{6} \cdot 0,12 \cdot 10^{-3}=1121,74 \mathrm{kN}
$$

Wartości te są już bardziej zbliżone do przedstawionych $\mathrm{w}$ tabeli 2 dla średnicy kojarzenia otworu piasty koła oraz osadzenia osi.

Tak więc na rysunku konstrukcyjnym zestawu kołowego powinny znajdować się następujące dane:

$>$ zakresy sił przy wtłaczaniu (wartości minimalne i maksymalne) dla następujących środków smarnych: oleju, łoju, mieszanki oleju i łoju oraz dwusiarczku molibdenu $\mathrm{MoS}_{2}$,

$>$ pasowanie obejmujące otwór koła oraz osadzenie osi, skąd wynika wcisk minimalny oraz maksymalny,

$>$ pasowanie obejmujące otwór koła zębatego oraz tarczy hamulcowej oraz osadzenia osi, skąd wynika wcisk minimalny oraz maksymalny.

Należy wziąć pod uwagę, że warunkiem prawidłowego wtłaczania koła na oś zestawu kołowego jest spełnienie dodatkowych warunków:

-zapewnienie podczas wtłaczania prawidłowej ilości środka smarnego; zbyt mała ilość środka smarnego (nawet lokalnie) powoduje zjawisko zacierania piasty koła lub osadzenia osi, zbyt duża ilość smaru powoduje wypływanie dużej części smaru na zewnątrz i blokowanie całego procesu wtłaczania,

-prędkość wtłaczania powinna być zależna od typu zestawu kołowego, zastosowanego smaru oraz użytej prasy (wartość orientacyjna 0,5 do $5 \mathrm{~mm} / \mathrm{sek}$.) należy wziąć pod uwagę, że zbyt duża prędkość wtłaczania może wpływać na zmniejszenie współczynnika tarcia, -prasa do wtłaczania powinna:

$\Rightarrow$ posiadać manometr rejestrujący, odpowiednio wyskalowany i umożliwiający wyznaczenie graficznego wykresu, przedstawiającego siłę wtłaczania w funkcji i położenia koła na osadzenia osi w czasie wttaczania,

$\Rightarrow$ mieć wzorcowane urządzenie, które rejestruje przebieg siły wtłaczania $\mathrm{w}$ funkcji położenia części wtłaczanej na osi oraz

$\Rightarrow$ skala odciętych powinna odpowiadać co najmniej 0,5 krotności rzeczywistego przemieszczenia wtłaczanej części, skala rzędnych powinna być tak podzielona, żeby można odczytać wartość siły z dokładnością do 0,025 MN,

$\Rightarrow$ dokładność czujnika pomiarowego siły powinna wynosić $0,01 \mathrm{MN}$,

$\Rightarrow \mathrm{w}$ przypadku rejestracji krzywej w formie zapisu, wykres powinien umożliwić odczyt przemieszczenia $\mathrm{z}$ dokładnością $\mathrm{z}$ dokładnością do $1 \mathrm{~mm}$ i zmianą siły $0,025 \mathrm{MN}$,

$\Rightarrow$ przed przyłożeniem siły wtłaczania należy dokonać regulacji, polegającej na zerowaniu przyrządu rejestrującego. 
Wykres wtłaczania kół na osadzenia osi powinien spełniać następujące warunki:

$>$ wzrost siły wtłaczania powinien się rozpocząć, zanim przemieszczenie osadzenia osi w stosunku do koła osi wyniesie $30 \mathrm{~mm}$, a następnie wzrastać w sposób ciagły, jednakże powinien on pozostać $\mathrm{w}$ przedziale tolerancji, które zostały poddane przez konstruktora dla wtłaczanej części (patrz tabela 2),

$>$ zmniejszenie siły wtłaczania jest dopuszczalne w momencie, gdy przesunięcie osiagnie rowek do wtłaczania oleju,

$>$ maksymalna siła wtłaczania powinna być ponownie osiągnięta, jeżeli przesunięcie osiagnnie kolejne $25 \mathrm{~mm}$,

$>$ dopuszczalny jest spadek siły wtłaczania wynoszący maksymalnie $5 \mathrm{MN}(50 \mathrm{kN})$, podczas ostatniej fazy przesunięcia, wynoszącej 25 $\mathrm{mm}$.

W przypadku wątpliwości wynikających z przebiegu wtłaczania lub wykresu wtłaczania, należy przeprowadzić próbę wytrzymałości na prasie po 48 godzinach od chwili zakończenia procesu wtłaczania. Siłę $F$ pomiędzy wewnętrzną powierzchnią piasty montowanych części i osadzeniem osi wprowadza się stopniowo, aż zostanie osiagnięta wartość siły, która podaje konstruktor. Próba powinna trwać w czasie 30 sekund, w czasie których nie powinno dojść do wzajemnego przemieszczenia wtłaczanych części. Siła $F$, w przypadku osiagnięcia siły nieco mniejszej od minimalnej, powinna być większa o $30 \%$. Wynika to $\mathrm{z}$ tego, że współczynnik tarcia statycznego jest większy od współczynnika tarcia dynamicznego (podczas wtłaczania). Próbę taką można przeprowadzić (w miarę możliwości) dla wszystkich wtłaczanych części tzn. dla wtłaczanych kół zębatych, tarcz hamulcowych oraz kół. W przypadku połączenia skurczowego należy wykonać $10 \%$ prób wytrzymałości montażu z partii dostarczanych zestawów kołowych. Pomimo, że połączenie skurczowe jest przedstawiane jako alternatywne do połączenia wtłaczanego, to należy wspomnieć, że pomimo że cechuje się wysoką wytrzymałością, to w przypadku osiągnięcia przez koło wymiarów kresowych i konieczności jego stłoczenia mogą wystąpić bardzo poważne uszkodzenia osadzenia osi. W związ$\mathrm{ku} \mathrm{z}$ wprowadzeniem wstawek typu $\mathrm{K}$ (K- niem. „Kunststoffbremssohle”) dla nowo produkowanych wagonów towarowych, wyposażonych w dwuosiowe wózki Y25 trwałość kół zmniejsza się z 900000 km (z dotychczas stosowanymi wstawkami żeliwnymi GG klocków hamulcowych- niem. „Graugussbremssohle”) do $600000 \mathrm{~km}$. Sytuacja ta jest szczególnie poważna w przypadku zastosowania kół monoblokowych i stopniowego wycofywania z eksploatacji kół obręczowanych.

Jak wynika z przedstawionych analiz połączenie wtłaczane musi przenieść dwa rodzaje obciążeń, aby zapewnić bezpieczną eksploatację:
$>$ obciążenia poprzeczne,

$>$ obciążenia momentem skręcającym.

W przypadku kiedy połączenie wtłaczane nie może przenieść siły poprzecznej, wówczas zagrożenie bezpiecznej eksploatacji polega na tym, że nie jest możliwe dalsze prowadzenie zestawu kołowego w torze. Brak możliwości przeniesienia siły poprzecznej przez złącze wtłaczane jest uważany za dużo bardziej niebezpieczny dla eksploatacji, niż brak możliwości przeniesienia momentu skręcającego, który może spowodować obrót koła (niem. „Radverdrehens”)[7].

Czynnikami pojawiającymi się w eksploatacji, które powodują zwiększony moment obrotowy są miedzy innymi maksymalna wartość poślizgu, przewyższającego wartości normalne, występujące w eksploatacji, znacznie przewyższające wartości występujące na krzywej poślizgu oraz drgania skrętne. Przez poślizg (niem. „Längsschlupf”) rozumie się różnicę pomiędzy prędkością obwodową i prędkością liniową (jazdy) zgodnie ze wzorem:

gdzie:

$$
\mathrm{s}_{\mathrm{x}}=\frac{\mathrm{v}_{\mathrm{OBW}}-\mathrm{v}}{\mathrm{v}}
$$

$$
\begin{aligned}
& \mathrm{S}_{\mathrm{x}} \text { - poślizg wzdłużny } \\
& \mathrm{V}_{\text {obw- }} \text { - prędkość obwodowa } \\
& \text { v-prędkość liniowa (jazdy). }
\end{aligned}
$$

Drgania skrętne osi zestawu kołowego występują w wyniku:

$>$ pojawiania się momentów hamowania i rozruchu

$>$ momentów napinających, wynikających $\mathrm{z}$ toczenia.

Drgania skrętne, które pojawiają się w eksploatacji można podzielić na drgania skrętne samowzbudne oraz na drgania wzbudzane z obcego źródła. Oceniając wytrzymałość zmęczeniową należy zwrócić uwagę na fakt, że obciążenia zginające i skręcające działają asynchronicznie, a ich przebieg nie ma charakteru proporcjonalnego. Podczas gdy zginanie obrotowe jest zależne od prędkości pojazdu i występuje w dolnym zakresie częstotliwości tzn. od 0 do $30 \mathrm{~Hz}$, to drgania skrętne występują w zakresie częstotliwości pomiędzy 50 i $100 \mathrm{~Hz}$. Własności cierne pomiędzy kołem i szyną przedstawia charakterystyka zależności współczynnika przyczepności od poślizgu na rys.2.

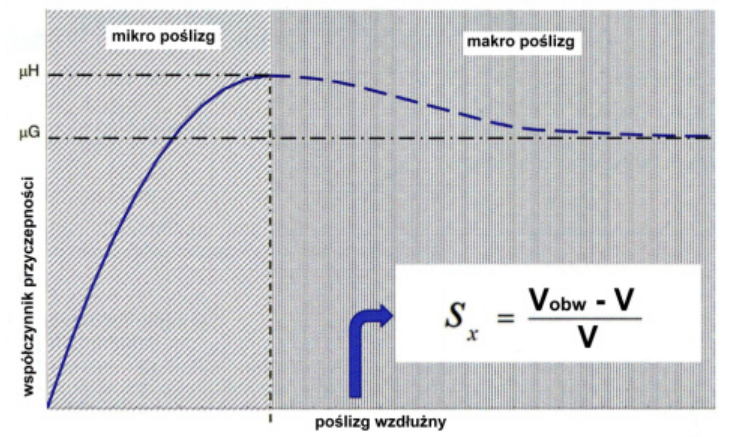

Rys.2. Zależność współczynnika przyczepności (niem. „Kraftschlussbeiwert) od poślizgu wzdłużnego (niem. „Längsschlupf”) wg [1] 
Drgania skrętne powstają z tytułu spadku na charakterystyce zależności współczynnika przyczepności od poślizgu wzdłużnego. Prowadzi to do zjawiska odtłumienia (niem. „Entdämmung”) w rozpatrywanym układzie. Spadek charakterystyki odbywa się w rejonie makropoślizgu (niem. „Makroschlupf”), a jego wielkość jest zależna od warunków otoczenia (warstwa pośrednia, wilgoć). Pochylenie krzywej pojazdu wzrasta, jeśli przy dobrych/średnich warunkach przyczepności eksploatacja odbywa się w zakresie makropoślizgu, natomiast krzywa opada przy większym tłumieniu własnym systemu. Niekorzystne warunki przyczepności (małe współczynniki tarcia np. przy wilgotnej szynie) dla przenoszenia sił trakcyjnych i hamulcowych, nie sa jednocześnie automatycznie krytycznymi dla procesu toczenia. $\mathrm{O}$ wiele bardziej muszą być badane sytuacje, przy których większy spadek charakterystyki, przedstawiającej zależność współczynnika przyczepności od poślizgu wzdłużnego. W takim przypadku eksploatacja odbywa się w zakresie makropoślizgu. Takie sytuacje powstają kiedy przy dużej sile pociagowej moment trakcyjny nie może być więcej przenoszony na szynach i zestawy kołowe są eksploatowane w zakresie makropoślizgu. Jako bardziej krytyczne muszą być uznawane sytuacje, w których warunki przyczepności zmieniają się wraz z trasa. Przykładem tego jest zmiana warunków meteorologicznych, co jest możliwe np. przy wjeździe do tunelu. Jeśli warunki zmieniają się $\mathrm{z}$ wilgotnych na suche, to wówczas zestaw kołowy wchodzi przy niskich współczynnikach przyczepności w zakres makropoślizgu, co jest pokazane na rys.3.

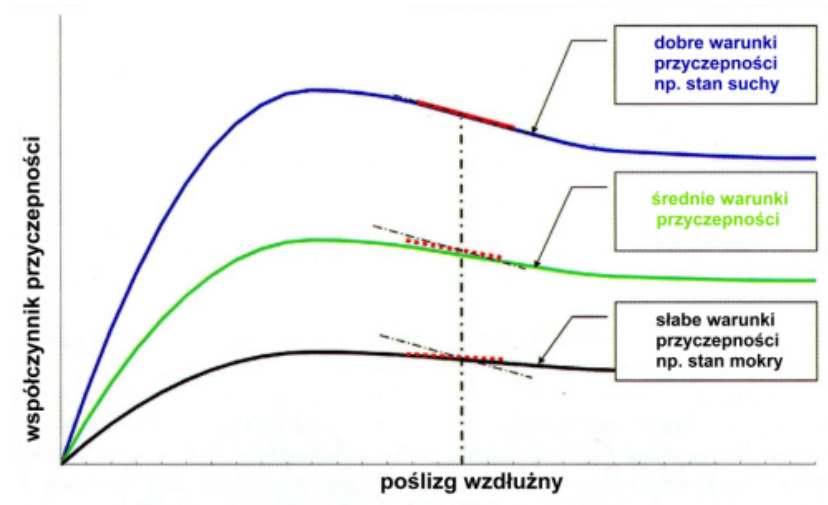

Rys.3. Wpływ warunków tarcia koło-szyna na charakterystykę współczynnik przyczepności-poślizg wzdłużny wg [1]

Jeśli ustala się moment skręcający w sposób eksperymentalny, należy ustalić czy pojazdy są z urządzeniami chroniącymi zestawy kołowe przed nadmiernym momentem skręcającym (niem.,, Rollierschutz”) czy też nie. Przebieg drgań skręcających bez urządzenia ograniczającego wartość momentu skręcającego zestaw kołowy jest przedstawiony na rys. 4 .

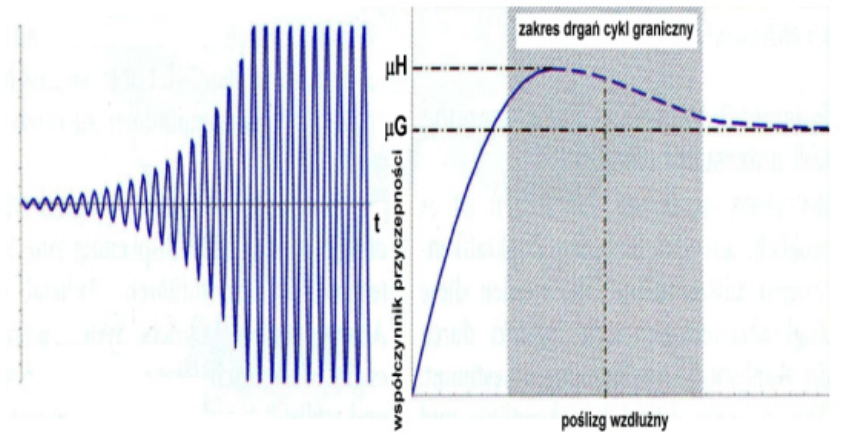

Rys.4. Typowy przebieg drgań skręcających bez urządzenia ograniczającego przed nadmiernym momentem skręcającym, z osiagnięciem cyklu granicznego wg [1]

Jak widać z rys.4 przebieg momentu skręcającego posiada tendencję wzrastająca, a następnie osiaga stała dużą amplitudę, która utrzymuje stałą wartość przez dalszą część przebiegu w zależności od czasu t. Jak wynika z [1] w wielu typach pojazdów można spotkać mnożące się przypadki zjawiska przekręcenia koła $\mathrm{w}$ stosunku do osadzenia osi (niem. „Verdrehungen”). Ponieważ nie można wykluczyć przyczyny tych zjawisk, że jest to nieprawidłowo wykonane połączenie wtłaczane, jednym ze środków, jest pomiar obciążeń działających na zestaw kołowy. Pomiary te pokazuja, że obciążenia skrętne pojawiające się w eksploatacji są znacznie większe, aniżeli przyjęte w trakcie projektowania zestawu kołowego.

Typowy przebieg momentu skręcającego zestawu kołowego, w którym występuje urządzenie ograniczające maksymalną wartość drgań skrętnych jest przedstawione na rys.5.

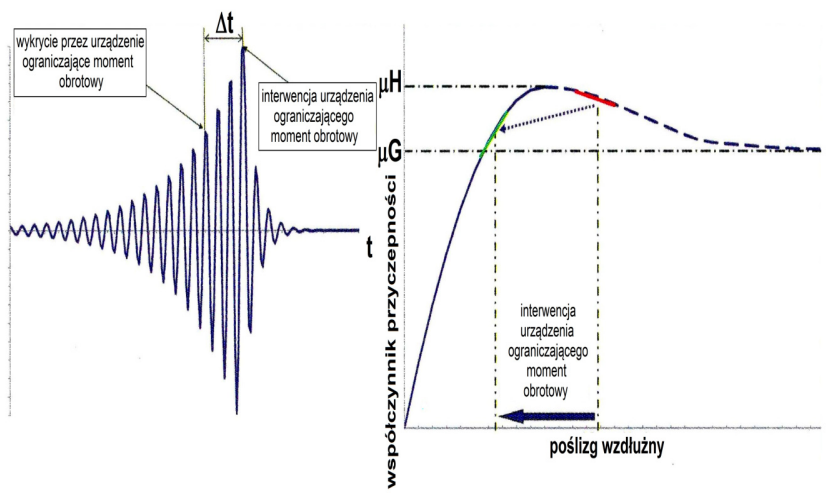

Rys.5. Typowy przebieg drgań skręcających z urządzeniem ograniczającym moment skręcający, bez osiagnięcia cyklu granicznego wg [1]

Jak widać z rys.5 amplituda drgań skrętnych ma tendencję wzrastającą $\mathrm{w}$ zestawie kołowym wyposażonym w urządzenie ograniczające moment skręcający ale aż do momentu, kiedy osiagnie ona wartość krytyczną. Amplituda o takiej wartości jest stopniowo tłumiona przez urządzenie, aż do całkowitego zaniku drgań.

Jeśliby uwzględnić amplitudę zastępczą, która uwzględniałaby wpływ drgań skrętnych oraz drgań giętnych, to należałoby skorzystać z zależności empirycznej: 


$$
a_{B K}=\sqrt[X m]{s_{a}^{x m}+t_{a}^{x m}}
$$

gdzie:

$\mathrm{s}_{\mathrm{a}}$ - średnia amplituda obciążeń skręcających,

$\mathrm{t}_{\mathrm{a}}$-średnia amplituda obciążeń zginających,

$\mathrm{x}_{\mathrm{m}}$ - współczynnik, który wynosi 1,5 .

Jak wynika z przeprowadzonych doświadczeń eksploatacyjnych maksymalne obciążenia, działające na zestaw kołowy i wynikające $z$ drgań giętych oraz drgań nie występują jednocześnie, co jest zilustrowane na rys.6.
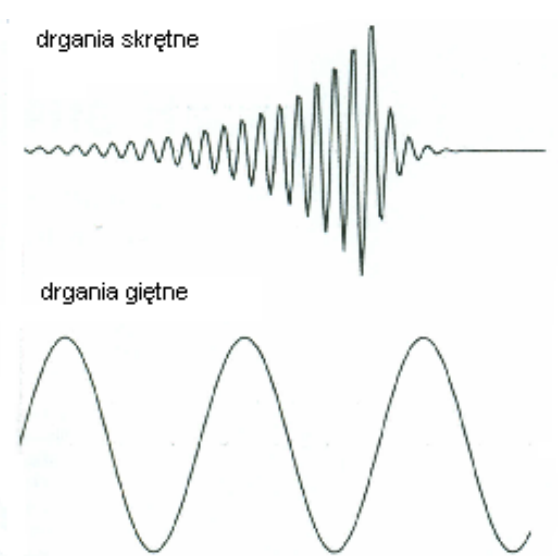

Rys.6. Asynchroniczny przebieg obciążeń, wynikających z drgań skrętnych oraz drgań giętnych zestawu kołowego

Wartość współczynnika $\mathrm{x}_{\mathrm{m}}$ wg współczesnych poglądów jest założone zbyt konserwatywnie, biorąc pod uwage specyfikę obciążeń działających na zestaw kołowy. Pomimo, że wielu fachowców uważa obecnie, że udowodnienie wytrzymałości wg metody $\mathrm{z}$ dużą rezerwą wytrzymałości prowadzi do zbyt konserwatywnych wyników, a w eksploatacji nie powstają uszkodzenia zmęczeniowe spowodowane obciążeniami momentem skręcającym, to należy wyjść z założenia, że w wielu przypadkach powstaja problemy wykazania odpowiedniej wytrzymałości, pomimo, że nie powstają żadne problemy techniczne. Nie jest znana również obecnie metoda, która pozwala na prawidłowe oszacowanie maksymalnego momentu skręcającego lub odpowiadającego jemu obciążeniu zmęczeniowemu.

\section{KRYTERIA OBCIĄZENIA POLĄCZENIA WTLACZANEGO MOMENTEM SKRECA- JACYYM}

Na obecnym etapie projektowania złącz wtłaczanych zestawów kołowych należy wziąć pod uwagę moment tarcia, który przeciwstawia się momentowi obrotowemu jaki wywołuje siła tarcia między kołem, a szyną przyłożona na powierzchni tocznej. Moment obrotowy sił tarcia jaki przenosi połączenie wtłaczane koło-oś zestawu kołowego wyznacza się ze wzoru:

$$
\mathrm{M}_{\mathrm{T}}=\pi \cdot 1 \cdot \mathrm{D} \cdot \mathrm{p} \cdot \mu \cdot \frac{\mathrm{D}}{2}=\pi \cdot 1 \cdot \mathrm{p} \cdot \mu \cdot \frac{\mathrm{D}^{2}}{2}
$$

Wstawiając wartości liczbowe do wzoru (25) dla osi wagonu towarowego o średnicy osadzenia $185 \mathrm{~mm}$ tzn. $\quad 1=185 \mathrm{~mm}, \quad \mathrm{D}=185 \mathrm{~mm}, \quad \mathrm{p}_{\mathrm{MI}(\mathrm{N}}=86,94$ $\mathrm{MPa}=86,94 \cdot 10^{6} \mathrm{~N} / \mathrm{m}^{2}$ otrzymuje się:

$\mathrm{M}_{\mathrm{T}}=\pi \cdot 0,185 \cdot 0,185 \cdot 86,94 \cdot 10^{6} \cdot 0,35 \cdot \frac{0,185^{2}}{2} \cdot 10^{-3}=55,98 \mathrm{kNm}$

Wartość momentu obrotowego $\mathrm{M}_{\mathrm{O}}$, które przenosi koło wyznacza się ze wzoru:

$$
\mathrm{M}_{\mathrm{O}}=\mu \cdot F_{T} \mu_{\mathrm{K}}=\mathrm{Q}_{\mathrm{MAX}} \cdot \frac{\mathrm{D}_{\mathrm{T}}}{2}
$$

gdzie:

$\mu_{\mathrm{K}^{-}}$współczynnik tarcia pomiędzy kołem i szyna,

Q $_{\text {MAX- maksymalny nacisk koła na szynę w }}$ kierunku pionowym, $\mathrm{D}_{\mathrm{T}^{-}}$średnica toczna koła.

Wstawiając dane liczbowe do wzoru (27) tzn. $\mu_{\mathrm{K}}=0,35, \mathrm{Q}_{\mathrm{MAX}}=165 \mathrm{kN}$ oraz $\mathrm{D}_{\mathrm{T}}=0,920 \mathrm{~mm}$ otrzymuje się:

$$
\mathrm{M}_{\mathrm{O}}=0,35 \cdot 165 \cdot \frac{0,920}{2}=26,56 \mathrm{kNm}
$$

Wartość maksymalnego nacisku koła ustalono na podstawie analizy OR-9514 [9].

Współczynnik bezpieczeństwa $\mathrm{S}$ złącza wtłaczanego wyznacza się z zależności:

$$
\mathrm{S}=\frac{\mathrm{M}_{\mathrm{T}}}{\mathrm{M}_{\mathrm{O}}}
$$

Po wstawieniu danych liczbowych tzn. $\mathrm{M}_{\mathrm{T}}=55,98 \mathrm{kNm}$ oraz $\mathrm{M}_{\mathrm{O}}=25,56 \mathrm{kNm}$ do wzoru (29) otrzymuje się:

$$
\mathrm{S}=\frac{55,98}{25,56}=2,19
$$

$\mathrm{W}$ przypadku porównania sił $\mathrm{Y}=56 \mathrm{kN}$ oraz minimalnej siły wtłaczania $\mathrm{F}_{\mathrm{MIN}}=555 \mathrm{kN}$ współczynnik bezpieczeństwa znacznie wzrasta:

$$
\mathrm{S}_{1}=\frac{\mathrm{F}_{\mathrm{MIN}}}{\mathrm{Y}}=\frac{555}{56}=9,91
$$

Jak widać z przeprowadzonej analizy, moment obrotowy, który przenosi koła jest bardziej miarodajny dla bezpieczeństwa eksploatacyjnego złącza wtłaczanego. W przypadku sił poprzecznych złącze wtłaczane można uznać jako całkowicie bezpieczne, biorąc pod uwagę wielkość maksymalnych sił jakie pojawiają się w eksploatacji. Znacznie trudniejszym zagadnieniem technicznym jest przenoszony moment obrotowy przez koło, który musi zrównoważyć połączenie wtłaczane koło-osadzenie osi. Tutaj współczynnik bezpieczeństwa jest znacznie mniejszy i przekracza nieznacznie wartość 2 .

Obliczenie momentu obrotowego przenoszonego przez koło jest obarczone pewnym uproszczeniem. Wszystkie wielkości przyjęte do jego obliczenia przyjmuja jednocześnie maksymalne wartości. Takie podejście do zagadnienia można jednak wytłumaczyć 
jazdą pojazdu w warunkach quasi-statycznych z małą prędkością w łuku, co sprzyjałoby występowaniu współczynnika tarcia o dużej wartości tzn. 0,35. Jeśli tak to uzyskanie wartości Q i Y odbyło się w oparciu o założenie, że na wagon działają jednocześnie przyspieszenie pionowe $\alpha$ o wartości $0,25 \mathrm{~g}\left(2,45 \mathrm{~m} / \mathrm{s}^{2}\right)$ oraz przyspieszenie poprzeczne $\beta=0,15 \mathrm{~g}=1,47 \mathrm{~m} / \mathrm{s}^{2}$.

Rozstrzygnięcie problemu czy takie wartości przyspieszeń mogą się pojawić podczas jazdy quasi-statycznej wagonu, wymaga przeprowadzenia osobnej analizy, wykraczającej poza ramy tego opracowania.

Należy również pamiętać, że wytrzymałość (nośność) połączenia wtłaczanego ulega osłabieniu podczas eksploatacji wskutek działania korozji stykowej (frettingu).

Zjawisko to jest przedstawione na rys.7, gdzie u góry znajduje się połączenie wtłaczane bez zwisów piasty ponad osadzeniem osi) oraz na dole znajduje się połączenie wtłaczane ze zwisami piasty ponad osadzeniem osi) .

Porównując przebieg nacisków powierzchniowych dla połączenia wtłaczanego piasta koła monoblokowegoosadzenie osi bez zwisów piasty koła w stosunku do osadzenia osi w stosunku do połączenia wtłaczanego $\mathrm{z}$ piastą osi ze zwisem na rys.7 można stwierdzić, że pierwszy rodzaj połączenia jest mniej korzystny tzn. połączenie jest mniej „szczelne”. Świadczy o tym większa wartość nacisków powierzchniowych na końcach (krawędziach) połączenia wtłaczanego (punkt $1 \mathrm{i}$ 20 na rys.7) z piastą koła ze zwisami. Wówczas można wnioskować, że czynniki powodujące korozję stykową jakimi są „,zanieczyszczenia” czy też czynniki atmosferyczne typu $\mathrm{CO}_{2}, \mathrm{SO}, \mathrm{SO}_{2}$ są mniej groźniejszym zjawiskiem. Fretting określa się również jako zjawisko oscylacyjnego ślizgania o małej amplitudzie elementów będących w styku, którego rezultatem jest uszkadzanie i zużywanie warstwy wierzchniej. Zjawisko to ma swoją przyczynę w różnicy pomiędzy sztywnością osadzenia osi oraz piasty koła.

Wystapieniu frettingu na powierzchni osadzenia piasty koła bosego na osadzeniu osi przemawiałoby następujące czynniki:

-bardzo duża gładkość łączonych powierzchni osadzenia osi oraz piasty koła (tzn. $R_{a}=2,5 \mu \mathrm{m}$,

-stałe występowanie obciążeń cyklicznych, co powoduje „mikro-poślizgi” obydwu powierzchni łączonych, -stałe narażenie zestawu kołowego na działanie czynników atmosferycznych, przy czym należy zaznaczyć że tlen zawarty w powietrzu jest czynnikiem bardzo sprzyjającym powstawaniu korozji stykowej (znacznie bardziej sprzyjającym niż azot).

Korozja stykowa jako efekt stałego „rozszczelnienia” połączenia wtłaczanego. Zjawisku „fretingu” (korozji stykowej) trudno jest zapobiec, a można jedynie łagodzić jedynie jego skutki. Najważniejszym czynnikiem sprzyjającym powstania korozji stykowej jest ruch oscylacyjny (max.130 $\mu \mathrm{m})$, który jest pokazany na
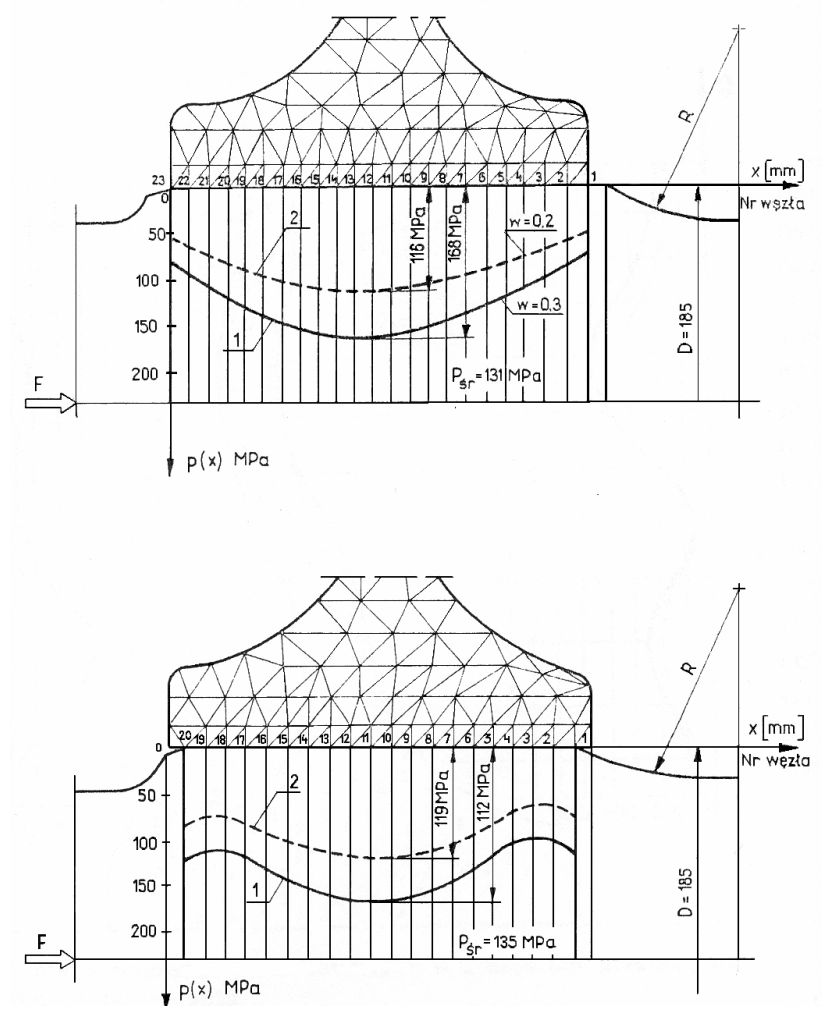

Rys.7. Zjawisko rozkładu naprężeń pomiędzy piastą koła oraz osadzeniem osi zestawu kołowego

rys.8. Jak wynika z hipotezy Waterhausena zużycie frettingowe osiaga maksymalną wartość wtedy, gdy ruchy oscylacyjne w kierunku wzdłużnym osiagną amplitudę o wartości mniejszej lub równej $25 \mu \mathrm{m}$

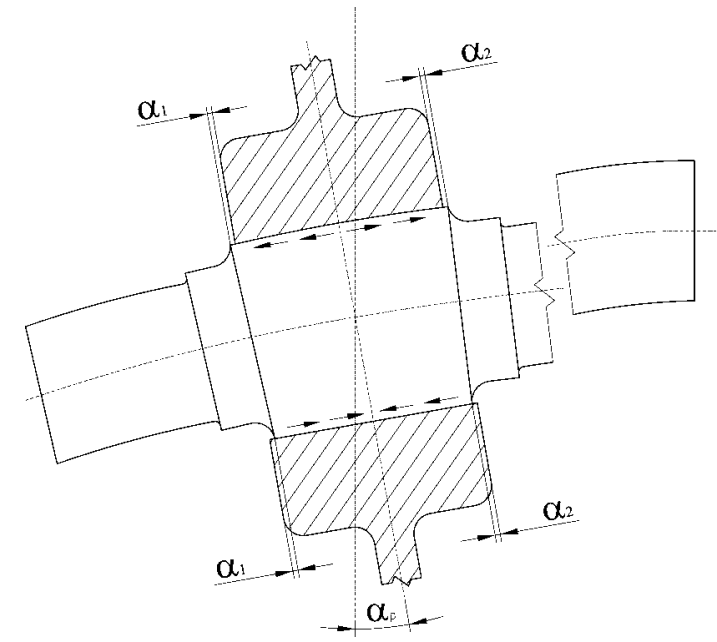

\section{WNIOSKI}

1. Metodyka projektowania osi zestawów kołowych pojazdów tocznych oraz trakcyjnych, przedstawiona odpowiednio $\mathrm{W}$ PN-EN 13103+A2:2012 [14] oraz PN-EN 13104+A2:2013 [15] podlega ciagłemu rozwojowi. Rozwój ten jest uwarunkowany zwiększeniem prędkości, co wymusza w przypadku budowy i modernizacji zmusza zarządce infrastruktury do stosowania większych przechyłek na łukach toru oraz większych niezrównoważonych przyspieszeń. 
2. Zagadnienie drgań giętnych i skrętnych obciążających zestaw kołowy wymaga dalszych prac, zwłaszcza w zakresie empirycznym. Pozwoli to na bardziej dokładną ocenę, jaki jest wpływ ww. drgań na wytrzymałość statyczną oraz zmęczeniową połączenia wtłaczanego. Po zbadaniu empirycznym parametrów drgań, można przystąpić do tworzenia modeli fizycznych oraz matematycznych oraz programów symulacyjnych.

3. W związku z pojawiającymi się dodatkowymi zagadnieniami technicznymi, które wskazują na zwiększenie wytężenia złącza wtłaczanego konieczne jest zapewnienie właściwej jakości wykonania połączeń wtłaczanych. Kontrola jakości producenta powinna zwrócić szczególną uwagę na ten fragment zestawu kołowego. Ważna jest też obserwacja połączenia wtłaczanego koło-oś zestawu kołowego podczas przeglądów i napraw pojazdów.

\section{LITERATURA}

[1] Benker T., Weber T.: Torsionsschwingungen von Radsätzen -eine Herausforderung. Eisenbahningenieur 4/2015.

[2] Berger P., Minde F.: Die Besonderheit der Kraftschlussausnutzung zwischen Rad und Schiene beim Bremsen. ZEV rail. Sonderheft Tagungsband. Moderne Schienenfahrzeuge.41 Tagung. Technische Universität Graz 7 do 10 April 2013.

[3] Köhler G., Weber F.J.: Die Sicherheitsphilosophie bei der Konstruktion, der Produktion und dem Betrieb von Eisenbahnradsätzen. ZEV rail 135.Tagungsband SFT Graz 2011.

[4] Sobaś M.: Diagnostyka osi zestawów kołowych układów biegowych pojazdów trakcyjnych i tocznych. Pojazdy Szynowe $n r$ 4/2010

[5] Sobaś M. : Zabiegi technologiczne zwiększajace żywotność osi zestawów kołowych. Pojazdy Szynowe $n r$ $1 / 2011$
[6] Sobaś M.: Przedsięwzięcia zwiększajace prognozowana żywotność osi zestawów kołowych pojazdów trakcyjnych. Pojazdy Szynowe nr 4/2011

[7] Sobaś M.: Czynniki konstrukcyjne i technologiczne wpływajace na żywotność osi zestawów kołowych. Pojazdy Szynowe nr 3/2012

[8] Sobaś M.: Przyczyny pęknięcia osi napędnych oraz tocznych pojazdów w eksploatacji. Pojazdy Szynowe nr $1 / 2013$.

[9] Sobaś M.: Ekspertyza przyczyn pęknięcia osi zestawu kołowego o $\mathrm{nr} 018457339 \mathrm{w}$ wagonie towarowym weglarce typu EANOS nr 31515350855-3. OR-9514 Praca niepublikowana, przechowywana $w$ archiwum IPS ,, Tabor”.03.2009.

[10] Weber F.J.: Auf der Suche nach dem maximalen Radsatzwellen-Torsionsmoment. ZEV Rail Tagungsband Graz 2014.

[11] Karta UIC 510-2: Pojazdy doczepne. Warunki do stosowania kót o różnych średnicach $w$ układach biegowych różnego typu. 4-te wydanie z października 2002 oraz kwietnia 2004.

[12] Karta UIC 510-5: Dopuszczenie kót monoblokowychzastosowany dokument EN 13979-1.

[13] Karta UIC 813: Warunki techniczne na dostawe zestawów kolowych dla taboru trakcyjnego $i$ wagonów. Tolerancje i montaż.

[14] PN-EN 13103+A2:2012: Kolejnictwo. Zestawy kołowe $i$ wózki. Osie zestawów kołowych tocznych. Zasady konstrukcji.

[15] PN-EN 13104+A2:2013: Kolejnictwo. Zestawy kołowe $i$ wózki. Osie zestawów kołowych napędnych. Zasady konstrukcji.

[16] PN-EN 13260+A1: 2011: Kolejnictwo. Zestawy kołowe $i$ wózki. Wymagania dotyczace wyrobu.

[17] PN-EN 13715+A1:2011: Kolejnictwo. Zestawy kołowe $i$ wózki. Koła. Zewnętrzne zarysy wieńców kół.

[18] PN-EN 13979-1+A2:2011: Kolejnictwo. Zestawy kołowe $i$ wózki. Koła monoblokowe. Procedura dopuszczenia. Część 1: Koła kute i walcowane.

[19] PN-EN 15313:2010: Kolejnictwo. Wymagania eksploatacyjne dotyczqce obstugi zestawów kołowych. Utrzymanie zestawów kołowych pojazdów w eksploatacji $i$ wytaczonych z eksploatacji

[20] ISO:286:1998: System ISO dla tolerancji i pasowań część 1:Podstawy tolerancji, wymiarów i pasowań. 1998. 